\title{
The effect of an eight-week proprioception training program on agility, quickness and acceleration
}

\author{
Cengiz TASKIN ${ }^{1}$, Yonca Sureyya BICER ${ }^{2}$ \\ ${ }^{1}$ School of Physical Education and Sport, University of Batman, Batman, Turkey. \\ ${ }^{2}$ Faculty of Sport Science, University of Firat, Elazig, Turkey. \\ Address Correspondence to C. Taskin, cengiz.taskin@batman.edu.tr
}

\begin{abstract}
The effect of an eight-weeks proprioception training programme on agility, quicknessand acceleration in this study which aims at determining the effect of an 8-weeks proprioceptive training on agility, quickness and acceleration, 13 students studying at the school of physical education and sports, aged $23.46 \pm 2.57$ on average, participated as an experimental group. 13 students studying at the school of physical education and sports, aged $22.39 \pm 1.56$ on average, also took part in this study as a control group. In the training program for developing proprioception, a multi-directional, inclined balance board was used for anterior/posterior, lateral/medial, clockwise and anti-clockwise movements. An eight-weeks training program, which comprised of $5 \mathrm{sec}$ warm-up, $20 \mathrm{sec}$ proprioceptive training and $5 \mathrm{sec}$ cooling in a day, was performed for total 30 second for 3 days in a week. The first 5 meters for quickness, 10 and 15 meters for acceleration and for t-test for agility were considered, the measurements were obtained as pre-test and post-test ones. For the experimental group, before and after the training, the values were measured as 5 meters for quickness, 10 and 15 meters for acceleration and $1.09 \pm 0.05$ sec and $1.03 \pm 0.05$ sec, $1.92 \pm 0.11 \mathrm{sec}$ and $1.80 \pm 0.11 \mathrm{sec}, 2.61 \pm 0.12 \mathrm{sec}$ and $2.48 \pm 0.08 \mathrm{sec}, 10.69 \pm 0.64 \mathrm{sec}$ and $10.13 \pm 0.35$ sec for agility respectively. When compared to the values of quickness, acceleration and agility for the experimental group, a significant difference was found out $(\mathrm{P}<0.05)$. For the control group, before and after the training, the values were also given as 5 meters for quickness, 10 and 15 meters for acceleration and $1.05 \pm 0.08 \mathrm{sec}$ and $1.04 \pm 0.05 \mathrm{sec}, 1.88 \pm 0.05 \mathrm{sec}$ and $1.89 \pm 0.08 \mathrm{sec}, 2.53 \pm 0.11 \mathrm{sec}$ and $2.52 \pm 0.12 \mathrm{sec}$, $10.26 \pm 0.54 \mathrm{sec}$ and $9.97 \pm 0.34 \mathrm{sec}$ for agility respectively. When compared to the values of quickness, acceleration and agility for the control group, no significant difference was found out $(\mathrm{P}>0.05)$. In conclusion, it was determined that an 8 -weeks proprioceptive training developed the characteristics of quickness, acceleration and agility.
\end{abstract}

Keywords: Acceleration, agility, proprioception, quickness.

\section{INTRODUCTION}

Proprioceptive capabilities have great impacts on sportive performance. During sportive activities, performance development and decrease in risks of being injured depend on athletes' proprioceptive abilities because most of sportive activities are performed in a high speed (12). Knocking any person down is not as easy as knocking any dummy down. Furthermore, keeping posture is not a passive stability but an active process which involves proprioceptive feedback information. If a vertical axis passing from the center of gravity of an object is between the support points of the object touching on the ground, this object cannot be fallen. Information from pressure receptors in foot base makes us aware of shifting our gravity center to which direction at that time and doing extension to which part (10). Balance control is a motoric characteristic which includes planning and performing flexible movement types as well as integrating sensorial inputs (5). An athlete with nonawareness is always forced to an unprofessional posture. Awareness is regarded in two types including emotional and sensational by an athlete. Sensational perception involves body movements or sportive skills. Proprioception education which is wholly equivalent to sensational perception must be given importance by all athletes and this education must involve an important part of branch education. If there was not proprioception in athletes, they always needed to be alert and followed consciously even in order to do the simplest movement successfully. With this view, not only proprioception does not help daily activities, but also it is important for athletes with high performance indicators. For this reason, proprioceptive system is necessary for the appropriate function of joints in sport, daily life activities and some professional skills (2). There are 
three processes in perceiving any movement; firstly, statical joint position and then speed and amount of the movement are perceived. Finally, efferent (motor neurons) responses occur against afferent (sense neurons) ones and muscular tone is adjusted. All of these processes build up proprioception. Owing to this sense, central neural system-brain has information about body positions and movements, and they maintain posture and keep balance. Receptors which provide proprioception have certain characteristics for rapid adaptation. That is, receptors can create more sensitive messages and more balanced movements in joints with suitable exercise programs. Persons need developed proprioceptive senses to perform activities in coordination (17). Therefore, the aim of the study was to examine the effects of 8 weeks proprioception training on quickness, acceleration and agility.

\section{METHODS}

\section{Experimental Approach to the Problem}

This investigation involved sectional design to evaluate the effect of proprioception training over the agility, quickness, and acceleration. A total of 26 healthy male physical education students volunteered to participate in this study. Agility, quickness, and acceleration tests were used for subjects.

\section{Subjects}

A total of 26 healthy male physical education students (mean $\pm \mathrm{SD}$; age: $22.92 \pm 2.07$ years; weight: $73.46 \pm 9.70 \mathrm{~kg}$; body height: $1.78 \pm 0.07 \mathrm{~m}$ ) volunteered to participate in this study after having all risks explained to them before the investigation. They were divided randomly into 1 of 2 groups: Proprioception training group (PTG; $n=13$ ) and control group (CG; $\mathrm{n}=13$ ). The mean $(\mathrm{SD})$ age was $23.46 \pm 2.57$ years, height was $1.76 \pm 0.07 \mathrm{~m}$, and weight was $73.23 \pm 9.87 \mathrm{~kg}$ for the Proprioception training group; the mean (SD) age was $22.39 \pm 1.56$ years, height was $1.80 \pm 0.07 \mathrm{~m}$, and weight was $73.69 \pm 9.53 \mathrm{~kg}$ for the control group. Following randomization, the 2 groups did not differ significantly $(p>0.05)$ in any of the dependent variables. All subjects were physically highly active and were experienced in performing various sprints and stretch-shortening cycle jumps through participation in various explosive-type sports activities (i.e., soccer, handball, athletics, and field) through their regular academic program. Specifically, their weekly volume of regular physical activity ranged from 6 to 8 hours. It also should be pointed out that all the subjects had at least 1 year of experience in endurance and strength training. The subjects in the control group did not participate in the training and participated only in the pre- and posttest measurements. Prior to data collection, all participants signed a university approved consent form. After receiving a detailed explanation of the study's benefits and risks, all subject signed an informed consent document that was approved by the local ethics committee. None of the subjects reported any medical or orthopedic problems that would compromise his participation and performance in the study.

\section{Procedures}

To evaluate the effect of proprioception training over the agility, quickness, and acceleration, we applied a testing procedure that included measurements of the agility, quickness, and acceleration mentioned by literature. In the present study, the proprioception training designed by Arslan (1) was used. Subjects' height is measured with an instrument sensitive to $1 \mathrm{~mm}$. Their body weight is measured with a weigh-bridge sensitive up to $20 \mathrm{~g}$ while they are dressed in only shorts (and no shoes). Height variable is in terms of meters, and body weight variable is in terms of kilograms. T test was used to evaluate agility of the subjects, 5 meters test was used to evaluate quickness of the subject, and 15 meters test was used to evaluate the acceleration. Each subject was familiarized with the testing procedures prior to data collection. Testing was conducted before and after 8 weeks of proprioception training. Subjects abstained from physical activity not related to the study during the testing period. Furthermore, during the testing periods and throughout the 8 weeks of proprioception training subjects were instructed to maintain normal dietary habits.

\section{Agility T-Test}

The Agility T-test was administered as originally set out by Semenick (16). Four cones were arranged in a $\mathrm{T}$ shape, with a cone placed $9.14 \mathrm{~m}$ from the starting cone and 2 further cones placed $4.57 \mathrm{~m}$ on either side of the second cone. All times were recorded using a photocell timing gate (Technology Fusion Sport Inc.), a height of 0.80 and $2.5 \mathrm{~m}$ wide in line with the marked starting point. Test was applied three times, with a 3-minute interval, and the best result was recorded for statistical analysis. The test setup is shown in Figure 
1. The intraclass reliability of the $\mathrm{T}-$ test was 0.98

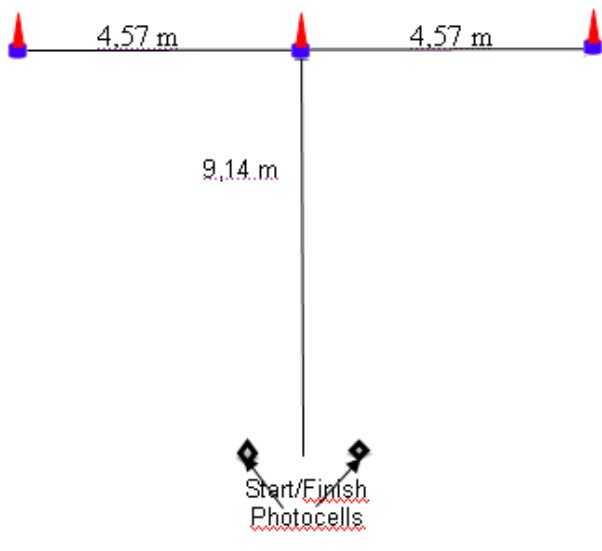

Figure 1. Agility T-test setup

$\underline{\varphi}$

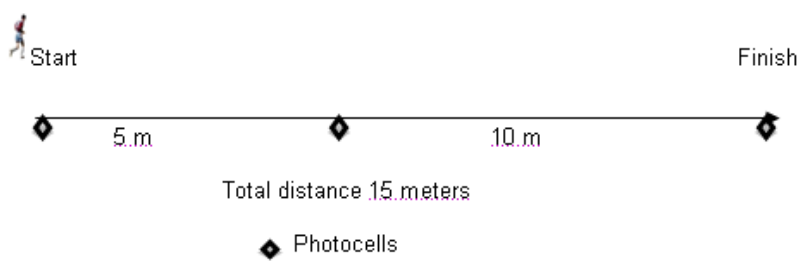

Figure 2. Quickness test for 5 meters and acceleration test for 15 meters

\section{Quickness and Acceleration Tests}

Photocells were placed at the start, $5 \mathrm{~m}$ (quickness), and $15 \mathrm{~m}$ (acceleration) in order to collect sprint times over the 2 distances. The starting position was standardized for all subjects. Subjects across 3 trials (14).

started in a 2- point crouched position with the left toe approximately $30 \mathrm{~cm}$ back from the starting line and the right toe approximately in line with the heel of the left foot. All subjects wore rubber-soled track shoes. Therefore, Quickness was evaluated for 5-m. Acceleration was evaluated using a 15-m test $(4,14)$. Test was applied three times, with a 3-minute interval, and the best result was recorded for statistical analysis.

\section{Statistical Analysis}

The SPSS statistical program (version 15.0) was used for data analysis. Standard statistical methods were used for the calculation of means and SD. The Kolmogorov-Smirnov test was used to determine if dependent variables were normally distributed. The Levene test was used to determine if there was homogeneity of variance. Paired t-tests were used to determine significant differences over time for each dependent variable. Unpaired t-tests were used to compare the proprioception training and control groups. For all analyses, the criterion for significance was set at an alpha level of $p=0.05$.

\section{RESULTS}

In the pretest shown in Table 1, the mean (SD) age is $23.46 \pm 2.57$ (years), height is $1.76 \pm 0.07(\mathrm{~m})$, weight is $73.23 \pm 9.87(\mathrm{~kg})$ for the proprioception training group; the mean (SD) age is $22.38 \pm 1.56$ (years), height is $1.80 \pm 0.07(\mathrm{~m})$, weight is $73.69 \pm 9.53$ (kg) for the control group.

Table 1. Data summary for the proprioception training group and control group.

\begin{tabular}{lcc}
\hline \multirow{2}{*}{ Variables } & Proprioception Training Group $(\mathrm{n}=13)$ & Control Group $(\mathrm{n}=13)$ \\
\cline { 2 - 3 } & Mean \pm SD & Mean \pm SD \\
Age (year) & $23.46 \pm 2.57$ & $22.38 \pm 1.56$ \\
Height $(\mathrm{m})$ & $1.76 \pm 0.07$ & $1.80 \pm 0.07$ \\
weight $(\mathrm{kg})$ & $73.23 \pm 9.87$ & $73.69 \pm 9.53$ \\
\end{tabular}

Table 2. Comparison of the pre-training and post-training relative quickness, acceleration, and agility with respect to Proprioception Training Group and Control Groups.

\begin{tabular}{|c|c|c|c|c|c|c|c|c|}
\hline \multirow{2}{*}{ Variables } & \multicolumn{4}{|c|}{ Proprioception Training Group } & \multicolumn{4}{|c|}{ Control group } \\
\hline & Different Mean & SD & $\mathrm{t}$ & $\mathrm{P}$ & Different mean & SD & $\mathrm{t}$ & $\mathrm{P}$ \\
\hline $\begin{array}{l}\text { Quickness } \\
\text { (pre-training-post-training) }\end{array}$ & 0.06 & 0.01 & 2.600 & $0.023^{*}$ & 0.01 & 0.03 & 0.428 & 0.676 \\
\hline $\begin{array}{l}\text { Acceleration } \\
\text { (pre training-post training) }\end{array}$ & 0.13 & 0.04 & 3.208 & $0.008^{*}$ & 0.01 & 0.01 & 0.588 & 0.568 \\
\hline $\begin{array}{l}\text { Agility } \\
\text { (pre training-post training) }\end{array}$ & 0.56 & 0.29 & 4.099 & $0.001^{*}$ & 0.29 & 0.20 & 1.534 & 0.151 \\
\hline
\end{tabular}

${ }^{*} \mathrm{P}<0.05$ 
Table 3. Comparison of the dependent variables in circuit training group and control groups.

\begin{tabular}{|c|c|c|c|c|c|c|}
\hline Dependent Variables & Independent Variables & $\mathrm{N}$ & Mean \pm SD & Mean Difference & $\mathrm{t}$ & $\mathrm{P}$ \\
\hline Quickness (s) (pre training) & $\begin{array}{l}\text { Proprioception Training Group } \\
\text { Control Group }\end{array}$ & $\begin{array}{l}13 \\
13\end{array}$ & $\begin{array}{l}1.09 \pm 0.05 \\
1.05 \pm 0.08\end{array}$ & 0.04 & 1.588 & 0.125 \\
\hline Quickness (s) (post training) & $\begin{array}{l}\text { Proprioception Training Group } \\
\text { Control Group }\end{array}$ & $\begin{array}{l}13 \\
13\end{array}$ & $\begin{array}{l}1.03 \pm 0.05 \\
1.04 \pm 0.05\end{array}$ & -0.01 & 0.634 & 0.532 \\
\hline Acceleration (s) (pre training) & $\begin{array}{l}\text { Proprioception Training Group } \\
\text { Control Group }\end{array}$ & $\begin{array}{l}13 \\
13\end{array}$ & $\begin{array}{l}2.61 \pm 0.12 \\
2.53 \pm 0.11\end{array}$ & 0.08 & 1.864 & 0.075 \\
\hline Acceleration (s) (post training) & $\begin{array}{l}\text { Proprioception Training Group } \\
\text { Control Group }\end{array}$ & $\begin{array}{l}13 \\
13\end{array}$ & $\begin{array}{l}2.48 \pm 0.08 \\
2.52 \pm 0.12\end{array}$ & -0.04 & 1.011 & 0.322 \\
\hline Agility (s) (pre training) & $\begin{array}{l}\text { Proprioception Training Group } \\
\text { Control Group }\end{array}$ & $\begin{array}{l}13 \\
13\end{array}$ & $\begin{array}{l}10.69 \pm 0.64 \\
10.26 \pm 0.54\end{array}$ & 0.43 & 1.823 & 0.081 \\
\hline Agility (s) (post training) & $\begin{array}{l}\text { Proprioception Training Group } \\
\text { Control Group }\end{array}$ & $\begin{array}{l}13 \\
13\end{array}$ & $\begin{array}{c}10.13 \pm 0.35 \\
9.97 \pm 0.34\end{array}$ & 0.06 & 1.153 & 0.260 \\
\hline
\end{tabular}

As shown in Table 2, paired t-tests detected significant differences in pre- and post-tests for quickness, acceleration, and agility in Proprioception training group $(p<0.05)$. However, pre- and posttests did differ significantly in control group for quickness, acceleration, and agility $(\mathrm{p}>0.05)$.

As shown in Table 3, the proprioception training group and control groups did not differ significantly $(p>0.05)$ in any of the dependent variables.

\section{DISCUSSION}

Any statistically significant differences were not found in the experimental and control groups in terms of quickness, acceleration and agility before the 8 weekly proprioceptive trainings ( $P>0.05$; Table 2). Furthermore, there were no statistically significant differences in the values of quickness, acceleration and agility of the experimental and control groups after the 8 weekly trainings $(P>0.05$; Table 3). Before the trainings, the experimental and control groups did not show any significant differences in the values of quickness, acceleration and agility, which the participant students had a homogenous structure in terms of quickness, acceleration and agility values. The 8 weekly proprioceptive trainings developed quickness, acceleration and agility in the experimental group $(\mathrm{P}<0.05 ;$ Table 4). However, the 8 weekly proprioception did not develop quickness, acceleration and agility characteristics in the control group $(\mathrm{P}>0.05)$ (Table 5$)$. When the relevant studies and the literature were examined, some of them were similar to our study, but the others did not comply with our values. The relevant differences here resulted from the tests and the measurement methods used in the studies. The objective of proprioceptive trainings is to improve neuromuscular systems for complex activities. When performing static and dynamic activities, neural systems make body possible maintain its balanced position and reach information from peripheral receptors through afferent-efferent ways $(3,9,15)$. In one study, the proprioceptive training program was applied in 35 female handball players at an elite level, these handball players' dynamic postural check-ups were analyzed before and after the trainings. As a result of pre-test and post-test comparison, it was stated that the relevant training program developed the female handball players' dynamic postural check-ups and prevented them from possible injuries (8). Hoffman and Payne (7) researched the effects of proprioceptive training program in healthy individuals, applied the training program in the experimental group 3 days in a week for 10 weeks. They suggested that the proprioceptive training program increased the subjects' postural check-ups and it would be beneficial for human movements (7). Proprioceptive capabilities have great effects on sportive performance. In sportive activities, performance developments and decreases in risks of being injured depend on athletes' proprioceptive abilities because most of sportive activities are performed in a high speed (12). Panics et al. (13) studied on the effects of proprioceptive training program on the knee-joint position in female handball players. The 
research involved 15 female handball players in the experimental group and 16 handball players in the control group. As the proprioceptive training program was applied in the experimental group 20 min. for two days in a week during four months, the control group only kept on handball trainings (13). At the end of this study, the proprioceptive training program improved the knee-joint proprioception of female handball players in the experimental group significantly (13). Lephart et al. (11) assessed knee kinesthesia in gymnastic persons. Gymnastic persons had lower values in the determination of passive joint movements of knees and $73 \%$ quicker response time rather than the control group, and this situation was considered to be related with the proprioception development resulting from the long-term trainings (11). In another study, the wobble board trainings were performed in the rugby players for 5 weeks and important developments were seen in both ankle and kneejoint position senses of athletes after the trainings (18). Hazar et al. (6) explained that balance affected agility in children in a positive way before puberty.

In conclusion; proprioceptive are important perceptual functions for all movements in order to do activities right and protect balance. All exercises indicate proprioceptive responses at a certain level. Improvements in athletes' performances are based on proprioceptive capabilities during sportive activities. Most of sportive activities are performed in high quickness. Exercises which represent proprioceptive developments are considered to develop movements applied in high speed such as agility, quickness and acceleration, and thus it will lead to increases in sportive performances. KAYNAKLAR

1. Arslan F, Kaya M, Taskin H. The effect of an eight week proprioception training programme on knee joint proprioception in taekwondo athletes. International SportMed Journal, 2013; 14(3): 99-102.

2. Ageberg E, Roberts D, Holmstrom E, Friden T. Balance in single-limb stance in healthy subjects - reliability of testing procedure and the effect of short-duration submaximal cycling. BMC Musculoskelet Disord, 2003; 27(1): 14.

3. Balter ST, Stokroos RJ, Akkermans E, Kingma H. Habituation to galvanic vestibular stimulation for analysis of postural control abilities in gymnasts. Neurosci Lett, 2004; 366: 71-75.
4. Bloomfield J, Polman R, O'donoghue P, Mcnaughton L. Effective speed and agility conditioning methodology for random intermittent dynamic type sports. J Strength Cond Res, 2007; 21(4): 1093-1100.

5. Ferdjallah M, Harris GF, Smith P, Wertsch JJ. Analysis of postural control synergies during quiet standing in healthy children and children with cerebral palsy. Clinical Biomechanics, 2002; 17, 203-10.

6. Hazar F, Taşmektepligil Y. The effects of balance and flexibility on agility in prepuberte period. Spormetre, 2008; 4(1), 9- 12 .

7. Hoffman MA, Payne VG. The effects of proprioceptive ankle disk training on healthy subjects. Journal of Orthopaedic and Sports Physical Therapy, 1995; 21(2): 90-93.

8. Holm I, Fosdahl MA, Friis A, Risberg MA, Myklebust G, and Steen $\mathrm{H}$. Effect of neuromuscular training on proprioception, balance, muscle strength, and lower limb function in female team handball players, Clin J Sport Med, 2004; 14(2): 88-94.

9. Huston JL, Sandrey MA, Lively MW, Kotsko K. The effects of calf-muscle fatigue on sagittal-plane joint-position sense in the ankle. J Sport Rehabil, 2005; 14: 168-84.

10. İnal HS. Spor Biyomekaniği - Temel Prensipler. Ankara: Nobel Yayın Evi, 2004.

11. Lephart SM, Giraldo JL, Borsa PA. Knee joint proprioception: A comparison between female intercollegiate gymnasts and controls, Knee Surg Sports Traumatol Arthrosc, 1996; 4: 12124.

12. Lephart SM, Pincivero DM, Giraldo JL. The Role of Proprioception in the management and rehabilitation of athletic injuries. The American Journal of Sports Medicine, 1997; 25(1): 130-37.

13. Panics G, Tallay A, Pavlik A, Berkes I. Effect of proprioception training on knee joint position sense in female team handball players. Br J Sports Medicine, 2008; 42: 472-76.

14. Pauloe K, Madole K, Garhammer J, Lacourse M, Rozenek R. Reliability and validity of the T-test as a measure of agility, leg power, and leg speed in college-aged men and women. J Strength Cond Res, 2000; 14: 443-50.

15. Salaj SS, Milanovic D. AndJukic I. The effects of proprioceptive training on jumping and agility performance. Kinesiology, 2007; 39(2): 131-41.

16. Semenick D. The T-test. NSCA J, 1990; 12: 36-37.

17. Swanik C, Lephart S, Giannantonio F. Re-establishing proprioception and neuromuscular control in the ACL injured athlete. Journal of Sport Rehabilitation, 1997; 182-206.

18. Waddington G, Adams R, Jones A. Wobble board (ankledisc) training effects on the discrimination of inversion movements. Aust J Physiother, 1999; 45(2): 95-101. 